\title{
CONCEITO DO ATO ADMINISTRATIVO
}

\author{
alcino de Paula Satazar \\ Docente-livre - Catedrático interino \\ de Direito Administrativo na Facul- \\ dade Nacional de Diruito
}

\begin{abstract}
SUMARIO: Funçöes a atribuigäos do Estado - Divisäo do tunçōos - separaçâo de poderen - Funçōes legislativa, jurisdicional e administrativa - A tunção administrativa - $O$ ato administrativo - O fato administrativo - Conclusäo.
\end{abstract}

\section{PUNÇõES E ATRIBUTÇõES DO ESTADo}

1. A teoria do ato administrativo está necessária e intimamente ligada ao princípio clássico e tradicional da tripartição da atividade do Estado em legislativa, jurisdicional e administrativa.

São as três funções em que se desdobra a ação do poder público na realização dos fins do Estado. São as formes pelas quais o Estado cumpre suas atribuições.

Estas se referem à extensão do campo da atividade estatal, fixado segundo determinantes históricas, e indicam a matéria sujeita à ação do poder num dado momento da evolução política e social de cada nação. Aí se defronta o momentoso tema da maior ou menor intervenção do Estado na ordem econômica e social, em seus variados aspectos, o que, entretanto, constitui problema que não afeta a natureza daquelas funções.

Na esfera do direito administrativo, o fato dessa intervenção crescente é recebido e aceito tal como se apresenta, para ser regulado em sua projeção e em seus efeitos na ordem jurídica.

As atribuiçōes do Estado, sintetizando a tarefa, as operaçōes, os negócios que lhe são incumbidos, constituem, pois, o conteúdo da sua atividade. 
Este conteúdo, porque essencialmente variável e incerto, subordinado mesmo à evolução acidentada da própria idéia de Estado, não se pode conter nos têrmos lógicos de uma definição ou na construção sistemática de um princípio.

Contudo, pondo em paralelo tais atribuições com a atividade dos particulares, a elaboração doutrinária chegou a classificé-las em três categorias:

a) as referentes à regulamentação da atividade privada, compreendendo as relações entre os indivíduos, por meio de normas imperativas ou supletivas, de caráter preventivo ou repressivo, e as referentes ao regime da propriedade particular;

b) as consistentes em fomentar, auxiliar e controlar a atividade privada, assegurando-lhe regularidade e continuidade; e

c) as que envolvem a substituição, no todo ou em parte da atividade privada pela do Estado.

Aí são consideradas as atribuições que têm sido ou podem ser exercidas pelos particulares, excluídas as que pertencem específica e essencialmente ao Estado, ${ }^{1}$ o que indica a precariedade das noções e discriminações doutrinárias neste terreno.

2. Tomada neste sentido próprio de medida da esfera de ação do poder público ou de delimitação dos direitos, faculdades ou prerrogativas do Estado, segundo uma nomenclatura muito usada, a expressão atribuições desde logo se diferencia nìtidamente, pelo significado, do têrmo funções. Enquanto que a primeira, como ficou dito, indica o que o Estado deve fazer, esta úlima revela o modo ou o meio de fazer. De sorte que as atribuiçóes se exercitam por via das funções; são idéias ou conceitos que se completam.

Nem sempre, todavia, essa diferenciação de terminologia é adotada e observada.

E mesmo frequiente entre as autores de direito público o uso cumulado e indiferente dos têrmos atriburiçöes e funções, para exprimir a mesma idéia de matéria ou objeto da competência do Estado.

Veja-se, ad exemplum, o autorizado e clássico BERTHÉLEMY quando, depois de enumerar muitos serviços e obras realizados norroalmente pelo Estado, observa como são extensas "as fun ções do govêrno e as atribuições das administraçc̃es públicas"."2

1 Bonnard, Précis, Rec. Sirey, 1926, p. 16; Gabmo Fraga, Der. Adm., $2 . "$ ed., México, 1939, p. 8 .

2 H. Bertrúleney, Traite Elém. de Droit Administratif, 13.* ed., Paris, 1933, p. 7. 
Também, entre nós, Tkmístocles Cavalcanti, no seu moderno e amplo Tratado de Direito Administrativo, segue essa indiscriminação de sentido entre as duas expressōes. ${ }^{3}$

Parece, contudo, injustificável ou, pelo menos, inconveniente o uso indistinto dêsses têrmos, que, tendo realmente significação diversa, servem para caracterizar fenômenos e idéias que se entrosam sem se confundirem.

\section{DIVISÃo DE FUNÇÕES E SEPARAÇÃo DE PODERES}

3. Nem se identifica, como é óbvio, a divisão das funç̧̄es com a dos poderes.

As várias modalidades da manifestação do poder de govêrno, vislumbradas já na concepção genial de ARISTóteles, deram lugar à teoria da divisão das funçōes, universalmente aceita e fundada em sólidas razóes científicas, que aqui é desnecessário examinar.

Quando se trata de atribuir cada uma dessas funções a um certo órgão de govêrno, é que surge a teoria da separação dos poderes, sujeita, já esta, a controvérsias fundamentais.

Não se confundem, observa o autorizado JELliNEK, a atividade do órgão e a função do Estado, derivando esta, no conceito do famoso mestre de Heidelberg, da relação entre a atividade do mesmo Estado e os seus fins. ${ }^{4}$

As funções se distinguem por certas caracteristicas atinentes aos meios pelos quais se exercitam e que possibilitam sua separação conceitual em têrmos mais ou menos nítidos, apesar das dificuldades técnicas de fixação das linhas que as configuram. Tal separação pode não coincidir, como normalmente sucede, com a divisão artificial dos poderes ou órgãos do govêrno, precisamente porque um princípio não está ligado essencialmente ao outro nem tira sua razão de ser dos mesmos fundamentos. 'A dissociação das funções se processa naturalmente, como um fenômeno que se impöe à observação, ainda que a cada uma delas não corresponda um determinado órgão; a separação dos poderes é um simples problema técnico de constituição e de organização.

3 Trat. cit., vol. I, p. 465. Dir ó acetado publicista: "Mais do que a estrutura zeral do Estado e das forthas de govêrno, talvez interesse so direito administrativo o estudo des funcóes do Betado. Aqui ce aprecian melhor as mas variadas formas de atividado $e$, principalmente, o limite de sua interveoço"s" (p. 467).

4. Teoria General del Estado, trad. de F. URRum, Buepos Aires, 1943, p. 496. 
Justa é a observação de R. Fernandez de Velasco :

En sintesis, se trata de determinar la naturaleza de las funciones del Estado, según su contenido, método que en su exprisión abstracta nada arguye contra la separación de poderes. La separación de poderes es un regimen. La separación de funcionies es un método. No hay incompatibilidad, ni oposición, ni exchusión. La separación de funciones, a lo menos aqui y para nosotra;, no aspira a sustituir la separación de poderes, sino a estudiar-los con un criterio objetivo"."

Hauriou, por sua vez, observa e censura a confusão levantada em tôrno do princípio da separação de órgãos e de funçว̃es. ${ }^{6}$

Trata-se, pois, aqui também, de noções distintas, que assim devem ser consideradas e examinadas ao se proceder à identifiıação e conceituação das manifestações da atividade do Estado nesse. fase complementar da realização de seus fins, c exercício da função administrativa que, na expressão de ARNALDO DE VALles, é a função central do Estado, "con cui esso provvede ai bisogni suoi come entità unitaria e della colletività, come somma dei singoli suo componenti". ${ }^{6-A}$

\section{FUNÇốES LEGISLATIVA, JURISDICIONAL E ADMINISTRATIVA.}

4. Expendidas estas considerações preliminares, tendentes a destacar a noção de função da de atribuiçōes, bem como da de atividade dos órgáos ou poderes do Estado, cumpre passar à questão da diferenciação entre as três funções pelas quais se concretiza - poder de govêrno.

O exame dos fundamentos invocados para essa discriminação e dos vários critérios adotados para conceituá-la e reconhacê-la na multíplice manifestação da atividade do Estado moderno servirá de subsídio ao estudo do problema particular do ato adininistrativo, de conceituação doutrinária imprecisa e controvertidia.

De vários pontos de vista ou segundo diferentes critérios tem sido feita a distinção entre as mencionadas funções.

Ora se toma em consideração o órgão que exercita a atividade, adotando-se, desta maneira, o critério subjetivo; ora se parte do

\footnotetext{
p. 377 . p. 156 .

6-A Teoria Giuridica cella Organizzarione dello Stato, Padova, Cedam, 1931, vol. 1 ,
}

5 El Acto Administrativo, Madri, 1929, p. 92.

6 Principics de Derecho Púb. e Const., trad. de Rutz Del Castulo, Madri, 1927, 
ponto de vista do conteúdo da atividade, ou mais especialmente de seus fins, encarada, assim, sob o aspecto material ou objetivo; ou, enfim, simplesmente a forma dos atos praticados pelos diversos órgãos no desenvolvimento daquela atividade, sendo que muitas vêzes se fundem êste e o processo subjetivista.

A matéria tem sido objeto de intensa elaboraçāo doutrinária, fértil em controvérsias e debates, indicando a dificuldade e delicadeza do problema que encerra e que é fundamental na disciplina das relações de direito pública.

5. Segundo a concepção subjetivista, orgânica ou formal, não importa a natureza intrínseca da atividade desenvolvida pelo poder público; qualifica-a o órgão que a exercita. As funções são formalmente legislativas, jurisdicionais ou administrativas, conforme sejam realizadas pelos poderes Legislativo, Judiciário e Executivo, respectivamente.

Este sistema pressupõe uma rígida separação dos três poderes. E como tal separação não é absoluta, sendo, ao contrário, relativa e flexível, na prática, sucede inevitàvelmente que o caráter formal e o material da função não coincidem. Haverá, por conseqüência, ato de uma função, considerada objetivamente, provindo indistintamente de diferentes órgãos constitucionais do Estado. $E$, ao revés, atos de funçöes distintas promanadas do mesmo órgão.

Daí a imprestabilidade do sistema, que foge às exigências de uma construção científica.

Dugurt considerou mesmo um êrro, lamentàvelmente generalizado, êste processo de discriminação das funçōes.

Admite o grande publicista francês que pode haver interêsse prático em levar em conta o órgão que realize êste ou aquêle ato, tendo em vista a possibilidade de recursos e a responsabilidade que acarretem. Mas observa que isto não implica em caracterizar as funções do Estado; sòmente aí se descreve o funcionamento de seus diferentes órgãos.

As funçōes jurídicas do Estado, que são as que devem ser consideradas, só se discriminam e se caracterizam, na lição do egrégio tratadista, do ponto de vista material, considerados os atos em sua natureza intima, "abstraction complète faite de l'organe, de l'agent qui est intervenu". $6-\mathrm{B}$

O professor Fernandez de Velasco, em estudo especializado da matéria, repudia igualmente o sistema subjetivista. 
Desde que os atos do Estado resultam da ação conjunta de seus próprios órgãos, não se pode discriminá-los em razão do urgão de que provenham : "en conclusión, los atos serán legislativas, ejecutivas o judiciales por una razón extraña o ajena a sua origen; $y$. el administrativo, como los demás, habrá de determinarse por razones objetivas, materiales, a menos de qưe se niegue su existencia".

Ainda hoje, porém, o processo formal de caracterização das funrzóes do Estado encontra adeptos, mesmo entre os mais autorizados e conhecidos doutrinadores, como CARRÉ DE MALEERG, ${ }^{8}$ Adolfo Merki, ${ }^{9}$ Marcel Waline.

Êste autor chega a dizer que a palavra administração designa antes certos órgãos do que certa atividade. ${ }^{10}$

A verdade, porém, é que não existe neste raciocínio un critério cientifico pelo qual se verifiquem e se apreendam as condiçöes específicas daquelas funções. Se eles se nos apresentam distintas e como tais consideradas na communis opinio, é inquestionável a necessidade de individuá-las pelo conteúdo ou pela naturezá, pela substância e não pelo acidente, seguindo, enfim, um método ligado ao aspecto material e não meramente formal.

Isto não exclui, de certo, a possibilidade e até mesmo a conveniência de considerar para determinados efeitos práticos, como observa DugurT, a proveniência do ato funcional.

Coexistirão, destarte, os dois sistemas, sem que, no entanto, um dêles, o formal, importe em assinalar á natureza do ato do pocier público.

6. Do ponto de vista objetivo, várias teorias se propõem explicar a natureza das funções do Estado.

Uma delas é a que toma por base os fins da atividade.

JELLINEK funda seu plano teórico exclusivamente na zonsideração da finalidade procurada. O Estado visa a obter três fins: um fim de direito; um fim de conservação; e um fim de cziltura.

7 Op. cit., p. 90.

8 Theorie Générale de l'Etat, 1920.

9 Teoria Ceneral del Derecho Administrativo, Madri, 1935.

Eis, no que toca à administraçäo, como opina o conhecido adepto da escola vienense: "La administracicn es aquella actividad del Estado que no es legislación ni justicia" (p. 13)

10 Man. Elém. de Droit Adm.. Sirey, Paris, 1939, 2.3 ed., p. 7 :

"On ne peut dire: les administrateurs sont ceux qui se livrent à un certain genre d'opérations, netcement distinctes des autres. On doit dire au contraize : la adminis tration, ce scont les opérations qu'elle qu'en soit d'ailleurs da nature intrinsèque, que font ler administrateurs"'. 
Inicialmente, as formas de realização dêsses diversos fins são duas: uma atividade normativa, fixando regras abstratas e outra de realização de problemas concretos, consistente ora em decisöes declarando um direito controvertido, ora na solução dêsses problemas na conformidade das normas jurídicas ou dentro de seus limites. Daí as três funções materiais: a legislativa e a jurisdicional, atendendo àquele primeiro fim; a administrativa, aos dois últimos. ${ }^{11}$

Também Hauriou se filia, em outros têrmos, ao critério finalista, segundo a definição que nos oferece nas últimas edições de seu conhecido Précis de Droit Administratif, depois de laboriosa evolução de seu pensamento, modificado sucessivamente, o que dá bem a idéia da complexidade do problema.

Na sua tão divulgada e discutida fórmula, a função administrativa, que distingue da governativa, "consiste essentiellement à faire les affaires courantes du public". ${ }^{12}$

Além de vaga, esta noção sofre o defeito de quantas teorias se atêm à finalidade da ação estatal para caracterizar as respectivas funçōes.

$O$ aspecto teleológico dos diferentes atos funcionais pode variar sem que, ainda assim, mude a sua essência. O fim a que tende o ato não the altera os característicos; não serve, por isso, para distingui-los no sentido material. $E$ o que com razão pondera DUguIT, aludindo ao exemplo trazido pelo próprio Hauriou, da discriminação dos contratos em civis, comerciais ou administrativos. Não se contesta que essa diferenciação tenha utilidade; o que se nega é que separem, por diferenças substanciais, essas categorias de atos considerados pela variedade dos fins a que tendem, ou seja, por circunstâncias ou aspectos exteriores, indiferentes à sua estrutura intima.

7. Outro sistema é o a que se tem denominado critério psicológico, resumido nesta fórmula: o Estado, que é uma pessoa, pensa e age. Pela legislação e a função jurisdicional exterioriza e concretiza o pensamento; pela ação realiza a função administrativa.

A amplitude de sentido da palavra ação destitui de interêsse - método proposto, que não chega a caracterizar com a desejada clareza e limitação de suas espécies a atividade do Estado. Por outro lado, não se pode excluir a idéia de pensamento na tarefa administrativa.

11 Op. cit., p. 496 e segs.

12 Précis, cit., 12." ed., Sirey, Paris, 1933, p. 15. 
8. Notável, pela originalidade, pela segurança de fundamentação e pela objetividade, foi a contribuição do insigne Liśon Dugurt, o admirável decano da Faculdade de Direito de Bordéus, para o estudo e elucidação do intrincado problema. Sua construção doutrinária, harmônica e sistemática, fiel a certas idśias matrizes, começa por deslocar os têrmos em que tem sido posta a questão.

A própria terminologia clássica sofre inovação, preferindo o eloquiente doutrinador dizer atividade jurídica dos governantes em vez de funções do Estado.

A questão começa por se restringir ao aspecto jurídico da atividade ou função do Estado. Essa atividađe jurídica se traduz em atos que produzem um efeito de direito. Certo é que o poder público realiza também atos que não têm êsse caráter, atos chamados materiais, mas que se ligam à função juridica, precedendo o ato juridico on dando-lhe execuçāo. Ficam, desta sorte, integrados em tal função.

E esta se distingue pela natureza interaa dos atos que a compõem.

Eis as palavras do autor:

"En un mot, toutes les fois que l'Etat intervient en vue d"un service public, il exerce une fonction juridique. Mais de quel ordre est cette fonction? Cela dépend, non point du service public en vue du quel il intervient, mais de la nature interne au point de vue du droit de l'acte qu'il accomplit. En d'autres termes, c'est uniquement d'après les modifications qui à suite de l'acte sont susceptibles de se produire dans l'ordonnandement juridique, soit dans le domaine du droit objectif, soit dans les situations juridiques subjectives, que doivent être distinguées des différentes categcries de fonctions juridiques de l'Etat'. ${ }^{13}$

Sob êsse aspecto, as funções do Estado assim se classificam:

- o Estado exerce a função legislativa, por qualquer de seus órgãos, sempre que expede um ato-regra, ou seja, quando emite uma disposição normativa ou construtiva, modificando o direito objetivo;

- exerce a função administrativa sempre que pratica um ato-condição, que é $o$ ato pelo qual investe alguém em uma situkição espesial predeterminada, bem como quando pratica um ato-subjetivo, que importa em criar uma situação simpllesmente indivicual,

13. Traité, ral. II. p. 154. 
e ainda quando realiza operaçöes materiais para assegurar o funcionamento de um serviço público;

- exerce, por fim, a função jurisdicional quando soluciona uma questão de direito. ${ }^{14}$

Em suma: o que caracteriza a função é o efeito que o ato leva à ordem jurídica estabelecida; e êsse efeito se gradua em três planos - uma situação geral (a lei), outra especial (um determinado estado) e outra individual (relação subjetiva).

9. Não se pode deixar de reconhecer na concepção do brilhante publicista francês uma aguda percepção dos fatos, uma segura análise da atividade estatal e uma persuasiva fôrça de argumentação.

Posta à margem a distinção das funçōes do Estado tomada segundo o ponto de vista do órgão, porque, em última análise, nega a própria diferenciação delas; e desprezada, por igual, a discriminação pelos fins - porque também não atende ao conteúdo da operação funcional, encarando-a pelo exterior, - impõe-se a consideração dos atos do poder pública, como atos jurídicos, pelos efeitos que êles produzem na ordem jurídica, pela projeção com que se transportam para o quadro da vida social, impondo alteraçōes no statu quo reinante.

O ato jurídico, na essência, é sempre o mesmo, provenha da autoridade pública ou da pessoa particular, tenha-se em vista um fim ou outro: é invariàvelmente uma declaração de vontade com o intuito de produzir um efeito de direito Seus elementos essenciais não variam. Devemos tomá-lo, então, nas consequiências com que se manifesta; e por aí chegaremos a caracterizar a função que traduz.

A objeção mais grave que se antepõe à fórmula de Dugurr para a determinação das funções, através das quais os governantes cumprem sua tarefa, é a de que, realizando-se pela função legislativa os atos-regra e pela administrativa tanto os atos-condição como os subjetivos, se esgotam aí tôdas as categorias dos atos jurídicos, não havendo outros que caracterizem a função jurisdicional.

O argumento tem sido refutado, ora pelo próprio DuGurT, ao traçar uma linha divisória separando a função administrativa da jurisdicional, em face da rigorosa análise do ato jurisdicional, em que encontra diferenças especificas; ora com apoio na classificação de Jìze, que acrescentou à do seu conspícuo colega mais uma espécie de atos - os que constatam uma situação jurídica ou um fato. 
É o que exporemos resumidamente em outra passagem desta dissertação.

10. Concluindo, pois, pela diferenciação das funções do F'stado segundo o critério objetivo ou material, alcançamos desde lojo uma conseqüência de particular interêsse para a conceituação do ato administrativo. Eque êste ato não tem já como pressuposto um determinado órgão, o órgão normalmente incumbido da adninistração; pode provir indiferentemente de qualquer dos poderes ou órgãos do Estado: do legislativo, do judicial, como do executivo.

O característico não está no órgão, encontra-se na própria função.

Daí não se referirem as definições do ato administrativo, na generalidade, ao Poder Executivo. Alude-se a ato da Administração; o ato administrativo provém. necessàriamente da Adninistração.

É o que se vê, por exemplo, na definição de OTto MAYE:R: "L'acte administratif est un acte d'autorité émanant de l'administration, acte qui détermine, vis-à-vis du-sujet, ce qui, pour lui, doit être de droit dans le cas individuel". ${ }^{15}$

Atenda-se, todavia, a que administração no sentido aí empregado não é uma entidade ou um órgão determinado; tem um significado genéricc de "conjunto de tôdas as pessoas coletivas que exercem a função administrativa de um Estado", como esclarece Marcelo Caetano. ${ }^{16}$

Outras definições se fundam nesta mesma base de atividade funcional, falando em autoridade administrativa como fonte do ato.

Assim a de Fritz Fleiner, que entende por ato administrativo "nada más que la ación de una autoridad administrativa llevada a cabo en virtud de una facultad de soberania encaminada a obtener un efecto juridico". ${ }^{17}$

Abandona-se, enfim, por êsse meio, a conceituação formal da função. Mas a definição do que seja administração, no sentido genérico de conjunto de órgãos e autoridades administrativas, renova a questão, se é que não a complica mesmo, diante de urna termirologia talvez escusada na técnica jurídica.

\footnotetext{
15 Le Droit Administratif Allemand, ed. francesa, Paris, 1903, vol. I, p. 120.

16 Tratado, Coimbra, 1944, vol, I, p. 122.

17 Instituciones de Der. Adm., trad. da 8." ed. alemä por S. A. GeNdin, 1533, Barcelona, p. 148.
} 


\section{A FUNÇÃo ADMmistratTiva}

11. Extrema-se nitidamente, como em resumo ficou exposto, a função legislativa das demais. Por aquela, estabelecem-se normas gerais, abstratas e obrigatórias, constituindo o corpo do direito objetivo. As duas outras, a função jurisdicional e a administrativa, importam na aplicação ou execução daqueles preceitos fundamentais. Com elas se completa e se integra a atividade do Estado, vista em dois momentos ou fases distintas - a elaboração da regra de direito e a sua individuação ou concretização.

Por isto mesmo chegou-se a sustentar que a duas únicas funções se reduzia, ao fim de contas, a atividade do poder público: a legislativa e a executiva.

Mais difícil e complexo é o problema da determinação das funções assim chamadas executivas: a jurisdicional e a administrativa.

A tarefa comum que, de um modo geral, se lhes destina, de realizar e individuar os superiores preceitos da lei põe num mesmo plano as duas espécies ou formas da atividade do poder público.

Tem-se pretendido, com grande cópia de argumentos, caracterizar a função administrativa pela finalidade genérica, mas que the seria exclusiva, de prover à satisfação das necessidades coletivas.

Pela jurisdição se asseguraria eventualmente a aplicação do direito vigente mediante a resolução de questōes de direito; pela administração seriam atendidos continuamente os interêsses e necessidades gerais. Administração em geral, diz OREste RaNELLETI, que desenvolve brilhantemente a tese, é "maneggio di affari, cura di interessi". ${ }^{18}$

Ainda se diz que pela função jurisdicional se aplica o próprio direito, constituindo isto o seu fim; enquanto que pela administração se desenvolve uma ação para a qual o direito, a que está subordinada, é apenas um meio.

Ora, essas generalizações, embora apresentem um fundo de verdade ou reflitam certos aspectos marcantes das diversas formas da ação do poder, não têm os requisitos de um sistema, pela imprecisão dos próprios têrmos.

A natureza da função administrativa há de ser determinada, como vimos, pelos efeitos dos atos que envolve, segundo o pensamento central de Duguir.

18 Lo guarantigie della giustixia nella publica amministranione, 5.^ ed., Milāo, 1937, 
12. A função administrativa compreende, como vimos, \& atos-condição e os atos-subjetivos. Incluindo-se nestas mesmas: categorias os atos-jurisdicionais, estariam êstes encerrados naquelc. função.

DUGuIT admite que lògicamente se poderia sustentar a dico tomia das funções em legislativa e administrativa, mas assinala. característicos específicos do ato jurisdicional, justificando ume terceira função. Este consistiria em constatar uma violação do direito e aplicar as medidas daí decorrentes.

Assim é definido:

"L'acte jurrisdictionnel ost donc en substance l'acte d'ordre: juridique accompli par un agent public comme conséquence logiques de la constatation qu'il a faite qu'il avait ou non violation du droit objectif ou atteinte à une situation subjective".

Inicialmente êsse ato depende de uma provocação, seja de quem fồ, sem a qual não terá lugar. Por êle se resolve sempre uma questão de direito; e afinal a solução se executa.

Em observação lúcida e exata o desembargador SEABRA FAGUNDES, dizendo ser DugurT o autor que mais nitidamente conseguiu caracterizar a função jurisdicional, assim resumiu a teoriá exposta:

"Mas o monento em que é chamada a intervir a função jurisdicional, o modo e a finalidade por que interiere no processo realizador do direito é que lhe dão os caracteres diferenciais. $O$ seu exercício só tem lugar quando exista conflito a respeito da aplicação das normas de direito, tem por objetivo especííico removê-lo, e alcança a sua finalidade pela fixação definitiva da exegese"." ${ }^{19}$

Destacado o ato jurisdicional dentre os atos-condição e os atos-subjetivos, delimitada está a função administrativa.

A função administrativa é então definida como aquela pelia qual os órgãos, os agentes públicos realizam atos-condição e atossubjetivos. Isto, porém, sob o aspecto exclusivamente jurídico. Porque há a considerar os atos materiais, levados a efeito para assegurar o funcionamento dos inumeráveis serviços públicos. Daí, então, cefinição mais ampla :

"L'Etat exerce la fonction administrative toutes les fois qu'il accomplit un acte condition ou un acte subjectif ou quand ses agents procèdent pour assurer le fonctionnement d'un servici? public, â l'accomplissement d'actes purement matériels". ${ }^{20}$

19 Op. cit., p. 20.

20 Op. cit., ps. 156 - 286. 
Examinando as diversas teorias explicativas da função administrativa, Gabino Fraga em tôdas elas encontra três elementos substanciais: a subordinação a uma ordem jurídica; a limitação dos efeitos produzidos pelo ato administrativo, os quais são ilimitados na função legislativa; e, finalmente, a ocorrência de atos materiais, pelo que conceitua aquela primeira função como sendo:"Una actividad del Estado que se realiza bajo un orden juridico y que consiste en la ejecución de actos materiales, o de actos que determinan situaciones juridicas para casos individuales". 21

Seabra Fagundes reduz êste conceito a têrmos mais simples, e ainda assim suficientemente compreensivos, definindo a funçāo em referência como "aquela pela qual o Estado determina situaçöes jurídicas individuais, concorre para a sua formação e pratica atos materiais".22

A síntese é inquestionàvelmente feliz e límpida. Inspira-se na idéia basilar de Dugurr, fundando-se na repercussão dos atos na ordem jurídica, embora não particularize a classificação do mestre de Bordéus, e abrangendo, na função, os atos materiais.

\section{O ATO ADMINISTRATIVO}

13. Se a função administrativa se caracteriza e se manifesta por meio de atos específicos, necessário é fixar-lhes a noçäo e a estrutura interna.

E relativamente moderna, pertencendo a um estádio mais recente da evolução do direito público, a expressão ato administrativo.

Surgiu, como quase todos os principios fundamentais do direito administrativo, na França e por ocasião da tempestuosa e fecunda revolução de 89 . E apareceu como uma conseqüência necessária do princípio da separação dos poderes, distinguindo-se as autoridades administrativas das judiciárias.

O primeiro surto legislativo da idéia foi uma lei do ano III, proibindo aos tribunais judiciários conhecer dos "atos de administração" de tôda espécie, seguida, no ano V, de uma resolução do Diretório que qualificava já de atos de administração "toutes les opérations qui s'exécutent par les ordres du gourvernement, par ses agents immédiats, sous sa surveillance et avec les fond's fournis par le Trésor public."

21 Op. cit., p. 67, n.॰ 48.

22 Op. cit., p. 16. 
A doutrina adotou polico depois, pela primeira vez, a designação hoje corrente para tais operações ou atos no Repertório dt: MERLIN, edição de 1812, onde aparece um aditamento com a expressão ato administrativo, definindo-o como "uma ordem, uma ação, um ato de um administrador relacionado com suas funções".

Antes disso, nos repertórios anteriores de DENISART e do GuYoT, só se emprega a palavra ato para relaçóes do direito civil e processual.

Os atos administrativos eram até entã̃o designados como atơ: do Rei, da Coroa, do Fisco, etc. ${ }^{23}$

Não havia mesmo interêsse no antigo direito, como observa DALLOZ, no Répertoire, em caracterizar os atos administrativos. Sob as governos absolutistas de então era inútil, de certo, procurar uma distinção entre as diversas funções ou atividades do Estado. Estas se confundiam nas mesmas autoridades.

Com a superveniência do regime a que se chamou Estado de Direito é que se impôs a necessidade de uma efetiva discriminação das funções de govêrno.

14. Naquela fase inicial, marcada pela legislação revolucionária, era amplo e genérico o conceito do ato administrativo, de: modo a compreender tôda a atividade da administração, como indicam as expressöes dos textos, revelando o intuito de reagir ac, extremo contra a interferência dos tribunais na ordem adminis. trativa.

Não tardou, todavia, um movimento de refluxo contra êsse: regime de absoluta exclusão do contrôle judicial.

MerLin insurgiu-se, em têrmos veementes, contra aquela desmedida amplitude do preceito legal, acoimando de bizarras e: infringentes da tradição e do bom senso as novas idéias. E HEN. RION DE PANSEY reiterou êsse pensamento, em obra publicada no ano de 1810, observando que o govêrno só é juiz das questõess suscitadas com a interpretação e execução de seus atos quando êle age "como govêrno e no interêsse geral da sociedade". Assimı não seria quando o litígio se estabelecesse tendo por objeto di.. reitos reais ou prestações transferidas por ato governamental para o patrimônio ou domínio do Estado. ${ }^{24}$

Era uma primeira restrição ao novo sistema de puro auto. contrôle da administração. Daí nasceu, com o desenvolvimento 
da discriminação dos atos governamentais segundo a natureza ou - grau do interêsse que tendiam a satisfazer, a velha e debatida dicotomia dos atos de império e atos de gestão, sistematizada e amplamente sustentada por LAFERRIÈRE.

15. Instituído o regime da separação de poderes e sendo dêle feita rigorosa aplicação, surgiu o critério subjetivo para a discriminação dos atos administrativos. Pois que os poderes eram rìgidamente separados, sem que um exercesse funções atribuídas a outro, vigoraria inevitàvelmente aquêle critério: os atos seriam caracterizados pelo órgão de que emanassem. Assim tôda a atividade administrativa estaria fora da alçada do Poder Judiciário.

Mas a prática atenuada daquele princípio, tal como passou a suceder, comportando um entrosamento de funções, havia de enfraquecer, conseqüentemente, tal critério subjetivo diante da confusão a que daria lugar a não coincidência do órgão com a função. Além disso, a instituição do contencioso administrativo, exigindo já uma discriminação de atividades $e$, finalmente, a atribuição, que veio a ser conferida aos tribunais, de conhecer das chamadas questões civis, acabaram por arruinar aquêle sistema artificial de determinação da natureza dos atos administrativos.

Alcançou então a doutrina novo estádio no desenvolvimento histórico do problema, fixando-se as funçōes do Estado segundo o seu conteúdo, ou seja do ponto de vista material, como ficou já exposto, obtendo-se, por esta forma, com a determinação da natureza da função administrativa, a dos atos administrativos.

16. A generalidade da doutrina conceitua o ato administrativo como um ato juridico, isto é, em têrmos sumários, uma declaração de vontade produzindo um efeito de direito.

Tal declaração há de partir necessàriamente de um agente incumbido da função administrativa, tendo, portanto, o poder legal que legitima $o$ ato $e$ lhe condiciona os efeitos. $\quad$ o requisito indispensável da competência, que corresponde, no direito privado, ao da capacidade.

Tomemos algumas das definiçōes mais autorizadas de ato administrativo.

HaURIov, a quem Dugurt atribuiu o mérito de haver pela primeira vez afirmado que o ato administrativo é um ato jurídico e, como tal, submetido ao direito, deu esta definição:

"São os atos administrativos atos jurídicos efetuados pela Administração no desempenho de seus serviços públicos e para o pleno exercício de seus direitos".

25 Prefácio de M. Haumou à obra EI Acto Adzinimatratio, de Vetuaco, cit., p. 7. 
Velasco considera ato administrativo:

"Toda declaración jurídica, unilateral y executiva, en virtud de la cual la ad'ministración tiende a crear, reconocer, modificar a extinguir situaciones juridicas subjetivas". ${ }^{26}$

$E$ acentuando êsse caráter de juridicidade acrescenta que o que não seja jurídico, ou, sendo jurídico, não expresse uma relação, não é ato administrativo.

OtTo MAYER expende o mesmo conceito por outras palavra:s:

"L'acte administratif est un acte d'autorité émanant de l'adnuinistration, acte qui détermine, vis-à-vis du sujet, ce qui, pour lui, doit être de droit dans le cas individual". ${ }^{27}$

E comenta o ponto de vista de JellineE, para quem ato administrativo é sinônimo de tôda e qualquer atividade da Administração, observando que por êste critério a instalação de uma sala de escola seria ato administrativo.

Surge aqui o ponto controvertido da questão, que assim poxle ser resumida; o ato administrativo compreende tôda a atividade da Administração, inclusive as simples operações materiais?

A construção de uma obra pública, uma operação militar, o fato material da prisão, o reconhecimento de uma firma, a preleçäo de um professor não importam em uma declaraçäo de vontade nem produzem desde logo um efeito de direito. Porlem ser, ainda cssim, considerados atos administrativos?

Alguns autores, como já vimos em Velasco, não o admitem.

Marcelo Caetano, professor da Faculdade de Direito de Lisboa, é dos que endossam êsse ponto de vista. Não considera atos administrativos "os fatos que não tenham caráter voluntário ou qu£, tendo-a, não definam situações jurídicas individuais pela aplicação das normas a casos concretos", excluídas assim as meras operaçióes administrativas. Daí, e porque excluiu também do ccnceito o regulamento, conclui que a categoria dos atos de administração é muito mais ampla que a dos atos administrativos ${ }^{28}$

Esta discriminação é adotada também por Vel.Asco, que considera da primeira categoria nāo só os atos da chamada administração consultiva como também os de natureza contratual e outros individualmente: enumerados.

\footnotetext{
26 Op. cit., p. 16.

27 Op. cit., p. 120.

28 Tratado, p. 222.
} 
17. Opondo restrições a esta orientação doutrinária que exclui peremptòriamente os chamados atos ou operações simplesmente materiais do conceito de ato administrativo, nêle contemplando apenas as declarações ou decisões com efeito jurídico, manifesta-se a grande maioria dos autores, admitindo, de um modo geral, que a expressão ato administrativo possa ser tomada em sentido estrito ou amplo.

SaNTI Romano, o notável professor da Universidade de Roma, depois de observar que é muito incerta a noção dessa figura jurídica, menciona os vários sentidos em que a lei e a doutrina italianas a tomam: ora como atos que emanam do Poder Executivo, exclusive os decretos-legislativos e os decretos-leis, mas inclusive os regulamentos e instruções; ora compreendendo "as manifestações especiais e concretas da administração pública", mesmo os atos materiais; ora só as manifestações que envolvam certos atos do domínio do direito privado; ora, finalmente, as decisões ou "declarações especiais de direito público da autoridade administrativa".

Indica esta última acepção como a que tem prevalecido na doutrina, a exempio do que sucede no direito privado quanto aos atos ou negócios jurídicos e nesse sentido estrito é que passa a considerar a matéria. ${ }^{29}$

RANELLETTI declara expressamente que os atos e fatos administrativos podem ser jurídicos ou não, conforme produzam, ou não, efeitos de direito. Os atos administrativos em geral assim se distinguem: em sentido estrito ou meros atos administrativos e atos administrativos - negócios jurídicos. Estes são declarações de vontade da autoridade administrativa visando a um determinado efeito jurídico (a nomeação, a concessão de serviço público); aquêles não encerram uma declaração de vontade do órgão administrativo dirigida no sentido de determinado efeito (um parecer, um atestado, o registro de um ato ou fato como prova dos mesmos). As operações materiais são conceituadas como fatos administrativos, que tanto podem ocorrer independentemente de um ato, como em execução do mesmo, ou ainda constituindo a própria declaração de vontade da administração. Nesta última hipótese, considera-se um ato administrativo. ${ }^{30}$

BONNARD considera que a função administrativa não é exclusivamente jurídica, como a legislativa, pois se exercita por meio de atos jurídicos e atos materiais. ${ }^{31}$

29 Corso, 3.4 ed., 1937, p. 222.

30 Op. cit., ps. 43 e 51.

31 Op. cit..p. 43 . FleINER entende que a expressão ato administrativo "abarca lo mismo hechos positivos, que acciones de naturaleza juridica (de derecho privado e público)" atribuindo-lhe também sentido estrito caracterizado pelo efeito juridico. Op. cit., p. 148. 
A questão apresenta, entretanto, outros aspectos que Dugurr explica com a habitual clareza de raciocínio.

Há, com efeito, numerosos atos ou operações materiais da administração que não têm conteúdo jurídico próprio. Nem por isso, entretanto, se põem fora da órbita do direito; permanecəm, ainda assim, sob um regime jurídico. Tais atos muitas vêzes são preparatórios ou antecedentes do ato administrativo strictu senso; ou são operaçôes de execução dêsse ato. De qualquer forma, estão ligados ao ato de caráter jurídico, seguindo, por conseguinte, a disciplina dêle.

Restarão ainda, é exato, certas operações que fogem a essas condições de dependência de uma decisão cu manifestação do agente do poder; mesmo assim, entretanto, estão submetidas ao regime legal. As lesões que ocasionarem determinam a responsabilidade do agente ou da administração. A lei, enfim, preside a tôdas as fases ou modalidades da atividade administrativa. ${ }^{32}$

RAGGI, outro reputado professor e tratadista italiano, insiste na necessidade da discriminação entre os atos materiais para solucionar o que chama a grave questão de saber se devem entrar no conceito de ato administrativo. Pondera que é necessário evitar os extremos: nem considerar todos os fatos materiais como atos administrativos, nem limitá-los às declarações de vontade. Se importam em uma manifestação tácita da vontade, tollitur quaesiio: aí está o ato administrativo. Se antecedem a declaração da vontade, preparando-a, ou se a seguem, dando-lhe execução, conservam aquêle caráter enquanto a vontade nêles atua; subordinam-se, porém, sempre, às condições e a forma legais. ${ }^{33}$

Gaston Jèze foi dos que mais profunda e amplamente estudaram a matéria do ato jurídico, examinando os problemas do direito administrativo, sistematizadamente, do ponto de vista da técnica jurídica.

Em obra que tem tido a mais larga divulgação, o sábio professor da Faculdade de Paris tomou os fundamentos da construção doutrinária realista de DUGUIT, completando-a e aperfeiçoandı-a.

Também não distingue, pela essência e pelo conteúdo, os ctos públicos dos de direito privado.

"Os atos jurídicos", define, "são manifestações de vontade de indivíduos - governantes, agentes públicos simples particulares

32 Traité, vol. 2, p. 298 ; e Las transts. del Der. Pub., trad. de A. Posada, Madri, 1926, p. 237.

33 Diritto Atrum., Pádua, Cedam, 1933, vol. I, p. 93. 
- no exercício de um poder legal e com o fim de produzir um efeito de direito. Este efeito consiste em criar uma situação jurídica, investir um indivíduo em tal situação ou fazer constar uma situação jurídica preexistente". ${ }^{34}$

Desta noção, em que é essencial a manifestação da vontade, ficam excluídos os atos materiais. Quando o carteiro entrega a correspondência ou quando o professor dá a aula, realizam atos materiais em que não existe nenhuma declaração de vontade. Se, no entanto, o carteiro desvia a correspondência ou o professor injuria alguém ao fazer a preleção, daí surgem efeitos de direito. Mas êsses efeitos não promanam do ato material lesivo, que é simples condição para o exercício do direito, decorrendo êste da vontade da pessoa lesada.

18. No direito brasileiro, a doutrina tem sido escassa, quase omissa, quanto a êste aspecto da noção, senão mesmo com relação ao próprio conceito do ato administrativo.

Era isto, em certo modo, o que observava o professor Alcmes CRUz, em seu conhecido livro de direito administrativo, ao afirmar que "a matéria de atos administrativos é muito vaga e obscura no Direito Público Brasileino"."35

Ainda hoje é parca a contribuição doutrinária para o estudo do assunto. Deixou-o à margem o próprio Tratado de VIverRos DE CASTRo, apesar de ter constituído essa obra apreciável serviço às nossas letras jurídicas.

Recentemente é que o desenvolvido e erudito Tratado de Direito Administrativo do Dr. Temístocles Brandão CavalcaNTI explanou a teoria dos atos administrativos. $\mathbf{E}$ aí se vê que foi insignificante o subsídio que the ofereceram os nossos publicistas. $^{36}$ Ainda aí, contudo, a noção do ato administrativo foi exposta em têrmos sumários.

Também examinou esclarecidamente a matéria o dr. Matos Vasconcelos, no seu valioso livro Direito Administrativo. Na parte referente ao assunto aqui exposto, filiou a noção do ato administrativo à definição legal do ato jurídico, adotando para os atos e fatos a distinção do direito civil. Sem aludir às operações materiais, considerou, acompanhado pelo prof. RoDRIGUEs VALE, que o fato administrativo é uma consequiência do ato admip. 46.

34 Los Principios Generales del Der. Adm., do prof. Garcm Ovrzbo, Madri, 1928.

35 Dir. Adm. Bras., Rio, 1914, 2.* ed., p. 37. 
nistrativo, afirmação que, com êste amplo teor, nos parece, data venia, inexata. ${ }^{37}$

Em excelente livro, que é um dos melhores trabalhos jurídicos da nossa moderna bibliografia jurídica, veio a se pronunciar sôbre a questão aqui focalizada o desembargador Miguel. SEABra. FAGUNDES, para quem "os atos administrativos podem ser, ou não, atos juríuicos": os primeiros quando modificam situações jurídicas, chamados então atos administrativos jurídicos; os demais quando não produzem tais conseqüências, - atos administrativos sem Efeito jurídico", - como os pareceres facultativos, os atos internos, as certidóes, os atestados, etc. ${ }^{38}$

Tito PRates da Fonseca, na mais recente das nossas obras de clireî́ administrativo em geral, expende considerações interessantes a respeito do tema em exame. Reconhece a cificuldade da fixação do conceito do ato administrativo, que vai desde o simples gesto do agente policial dirigindo o serviço do trânsito até o decreto do Presidente da República. É administração tudo quanto não se inclua ne esfera da ação legislativa ou jurisdicional. Como o ato administrativo é uma espécie do gênero ato jurídico, contém necessàriamente uma declaração de vontade, que não é um :equisito dêle, mas a própria essência. Em tais condições, as demais formas de atividade que não consistam numa exteriorizaçäio da vontade são estranhas à idéia de ato administrativo. ${ }^{39}$

19. Balanceando os dados do problema, expostos em resumo, parece-nos que se impóe, preliminarmente, como base para uma solução adequada, a teoria a que BonNARd, embora sem lhe emprestar plena adesão, chamou de teoria da atividade juridice.

Sem dúvida a administração se desenvolve por meio de atos os mais variados, compreendendo não só os que são animados de um impulso volitivo declarado como os que consistem em simples operações materiais.

Daí a dualidade dinâmica da função: atividade jứćclica e atividade material; aquela refletindo-se de imediato na ordem jurídica, a última produzindo alteraççes de natureza exclusivamente material.

37 M. Vasconcelos, Dir. Aćm., 1936; vol. I, p. 96; J. Rodrigues Valt, Curso de Dir. Adm., 1940, i. ${ }^{\circ}$ vol., p. 172.

38 O Contrồe des Atos Adms. pelo Foder Judiciário, Rio, 1941, n.* 20, p. 38.

39 Liğes de Dir. Adm., 1943. Cirne Lima chama atos administrativos "aos atos jurídicos praticados, segundo o direito administrativo, por pessoas administrativas" (Principios de Dir. Ádn. Eras., 2. ${ }^{2}$ ed., Pôto Alegre, p. 73). 
Só a atividade jurídica deve ser considerada na caracterização do ato administrativo, tido, assim, como uma espécie do gênero ato jurídico, segundo a observação de Tito PRates.

Os atos ou operaçōes materiais que formam a outra espécie de atividade não se incluem na noção de ato administrativo, por thes faltar o elemento substancial de todo ato juridico.

Não ficam, contudo, excluídos da disciplina jurídica; podem, até, produzir efeitos de direito, modificando situações individuais, mas êsses efeitos decorrem, não direta e imediatamente da ação praticada, surgindo, antes, da infração do regime a que está adstrita tôda a atividade administrativa, no amplo sentido.

E uma razão de ordem prática aconselha mesmo que se dê outra designação àqueles atos, atribuindo-se à expressão ato administrativo um sentido restrito e técnico, que evite confusões e incertezas.

Aceitando, em sintese, e nos seus fundamentos, a concepção realista de DUGUIT, posta por JÈzE em rigorosos lineamento técnicos, podemos adotar como expressiva da idéia de ato administrativo esta concisa definição de Gabino FraGA, o brilhante professor da Faculdade de Direito da Universidade Nacional do México: "o ato jurídico administrativo é um ato do Estado que determina situações jurídicas para casos individuais". Aí se compreendem tanto as situações juridicas subjetivas ou individuais como os atos-condição ou seja a aplicação de um certo status a um indivíduo. ${ }^{40}$

Seabra Fagundes faz um aditamento a essa definição, considerando ato administrativo, como vimos, "aquêles através dos quais - Estado determina situaçōes jurídicas individuais ou concorre para a sua formação". 11 Inclui, assim, os atos que antecedem o ato criador de situações jurídicas, como as certidóes, os atestados, o reconhecimento de firma, frisando, embora, que não são atơ jurídicos.

Não sendo atos jurídicos, não podem ser considerados, do nosso ponto de vista, como atos administrativos.

20. Sem dúvida, êste problema da conceituação do ato administrativo encerra considerável interêsse prático, mesmo nas organizações jurídicas que não adotam o sistema do contencioso administrativo. A falta de uma definição doutrinária assentada dessa

40 Op. cit., p. 144.

41 Op. cit., p. 31. 
figura jurídica, fixando pelo menos os seus traços fundamentais, leva à contingência, em que fica o legislador, de recorrer ao critério subjetivo e formal para caracterizar e regulamentar a atividade da administraçäo, agravando com inevitável casuísmo as dificuldades da matéria e impedindo a unificação e sistematização da disciplina dessa atividade no que toca às condições de formaçấo, de validade, aos efeitos e à revisão dos atos em que se desdobra.

Figure-se essa mesma hipótese no plano do direito privado relativamente à conceituação do ato jurídico e ter-se-á a representação de um estado de coisas caótico e inviável.

Impõe-se, por isto, a necessidade de uma definição teórica do sentido e do conteúdo da idéia de ato administrativo, de scrte a ser proveitosamente transportada para o terreno do direito positivo. De outra forma, a lei faltaria à indispensável condiçĩo de precisão e clareza, gerando a contradição e propiciando o arkítrio.

21. Em nossa legislação, só eventualmente se encontrará o têrmo ato administrativo, sendo empregadas freqüentemente as expressões atos da administração, atos ou decisões das autoridades administrativas, etc., sem precisão ou uniformidade de sentido

A lei n. ${ }^{\circ} 221$, de 20 de novembro de 1894 , e o decreto n. ${ }^{\circ} 1.939$, de 28 de agôsto de 1908, que a completou, deram e regularam ação fundada na lesão de direitos individuais por atos ou decisões das autoridades administrativas.

Já o decreto legislativo n..$^{0} 1.151$, de 5 de janeiro de 1904, aludia a atos das autoridades sanitárias praticados ratione inıperii, revivendo, assim, a obsoleta e discutida classificação fundacla na dupla personalidade do Estado ou num duplo aspecto do seu procedimento.

A Constituição de 1934, criando um tribunal administrativo. atribuiu-lhe competência para julgar "atos e decisōes definitivas do Poder Executivo"; e instituiu o mandado de segurança contra ato inconstitucional ou ilegal de qualquer autoridade.

A lei que regulou o novo instituto ( $\mathrm{n}^{\circ} 191$, de 16 de jeneiro de 1936) e o atual Código de Processo Civil (art. 319) reproduziram a expressão "ato de qualquer autoridade", considerando atos de autoridade "os de estabelecimentos públicos e de pessoas naturais ou jurídicas, no desempenho de serviços públicas".

O decreto-lei n. ${ }^{\circ} 1.174$, de 27 de março de 1939, faz referência, na ementa, a recursos contra atos administrativos.

São exemplos da mencionada imprecisão de terminologia. 
$\mathrm{Na}$ interpretação e aplicação das disposições relativas ao mandado de segurança, a nomenclatura usada tem dado margem, como é sabido, a dificuldades e dúvidas.

O Ministro Castro Nunes expõe e comenta, com brilho e reconhecida autoridade, as questões levantadas na justiça sôbre a extensão da medida, principalmente quanto ao sentido da palavra autoridade, sustentando que havia sido empregada no texto constitucional com a significação de funcionário público, excluindo, pois, as autoridades judiciárias. "Tudo isso está indicando, conclui o eminente constitucionalista, que foi para coibir o excesso de poder da administração que se instituiu o mandado de segurança"."22

A lei n. ${ }^{\circ} 191$ ampliou, porém, consideràvelmente o âmbito da medida, concedendo-a contra atos de quaisquer outras autoridades federais, inclusive legislativas, e ainda mesmo "contra atos das autoridades determinados na lei de organização judiciária."

Discutiu-se, então, a aplicação da regra quanto aos atos judiciais de um modo geral, entendendo o Ministro CASTRo Nunes que o mandado sòmente poderia atingir decisões para as quais não estivesse previsto em lei recurso com efeito suspensivo. ${ }^{43}$ Já o eminente jurista dr. Gabriel Passos, Procurador Geral da República, opinava que só os "erros de administração do juiz, do legislador e de qualquer autoridade" estariam sujeitos ao remédio do mandado. ${ }^{44}$

Seabra Fagundes focaliza também a questão, indagando se a expressão atos administrativos deve ser tomada como sinonímica de ato de qualquer autoridade, indagação a que, a seu ver, a jurisprudência não chegou a dar resposta satisfatória, "nem mesmo na época de maior voga do mandado de segurança". ${ }^{45}$

Bem se vê que estas dificuldades e embaraços provêm de uma terminologia legal incerta e casuística em tôrno da função administrativa, porque a verdade é que o objetivo central do mandado de segurança é exercer um contrôle eficaz sôbre os atos administrativos, pouco importando o órgão ou agente de que provenham.

Também no que se refere à responsabilidade civil do Estado é indispensável a exata conceituação do ato que a ocasione, discriminando-se $o$ ato administrativo do ato jurisdicional.

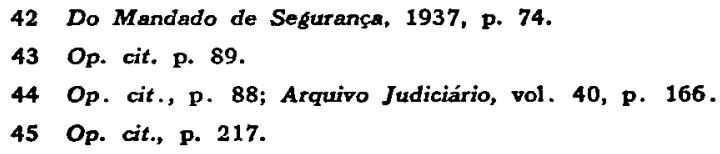


A doutrina já hoje reconhece a responsabilidade đo Estado por atos do Poder Judiciário de caráter não jurisdicional, o que encarece a necess:dade da diferenciação. ${ }^{46}$

\section{O FATO ADMINISTRATIVO}

22. Definido o ato administrativo, convérn estremá-lo do sato administrativo.

Segundo uma noção corrente da teoria geral do direito; $\infty$ fatos jurídicos são acontecimentos em virtude dos quais as relacões de dire:to nascem e so extinguem. Ou são naturais, independentes assim da vontade humana, e as suas consequiências são as determinadas na lei; ou são ações do homem produzindo efeitos que, ténto podem ser conformes a sua vontade como podem surgir independentemente dela. Na primeira hipótese, configura-se o fato jurídico pròpriamente dito; a segunda, o ato jurídico; e da última é exemplo o ato ilícito.

Fatos juridicos, como os atos jurídicos, ocorrem igualmente nas relações dominadas pelo direito ad̉ministrativo. São, aí, também, os primeiros, eventos determinantes de relaçóes previstas na lei. Por meio dêsses eventos se exerce a influência do mundo exterior na ordem jurídica.

Três espécies principais de fatos que produzem efeitos de direito assinala VELASCO:

a) os naturais, involuntários, independentes de qualquer ą̧ão, afৎtando igualmente as partes quando unidas por uma relação, como a morte de um funcionário, uma inundação, um incêrıdio e outros eventos censtituindo casos de fôrça maior;

b) fatos voluntários da Administração ou de um particular, legais ou ilegais;

c) atos jurídicos (declarações de vontade).

Os voluntários, criginados da Administraçäo, podem ser lę̧ais, quenio autorizados ou quando independam de autorização por se referirem ao exercício da atividade discricionária; ou ileģais, quanzo realizados sem a autorização devida, sem ato prévio que og condicione ou praticados em execução irregular dêsse ato. Os que provêm dos particulares podem determinar un ato administrativo de sanção."t

46 Minha Resp. do Foder Público por Atos Judiciais, Ruo, 1941; voto do Mirintro Orozimso Northto, in Jurisprudência do S.T.F., In prensa Nacional, vol. IV, p. 136.

47 Op. cit., p. 137. 
BIELsA considera que a atividade administrativa se concretiza em fatos e atos, que se distinguem segundo os princípios do direito privado.

Quando a Administraçăo decide sôbre diraito ou interêsse realiza o ato administrativo; quando, para realizar seus fins, exerce uma atividade material, esta se resolve em fatos administrativos, que geralmente são precedidos de um ato. ${ }^{48}$

Outros entendem que os chamados fatos administrativos se esgotam nas operações de execução ou realização dos atos administrativos. Aquêles são conseqüências dêstes, sem os quais não têm existência. E o ponto de vista de Matos Vasconcelos ${ }^{49}$ e Seabra Fagundes. ${ }^{50}$

Conceito mais amplo é o que expende RANELLETTI, para quem os fatos administrativos "são constituídos dos fatos materiais, das operações dos órgãos da administração que produzem uma modificação no mundo exterior e por meio dos quais o Estado ou outro sujeito de direito público exerce atividade de administração".

$E$ esclarece que podem ser realizados em execução de um ato administrativo, mas nem sempre será assim; terão lugar ainda que não se verifique um ato precedente como na hipótese da demolição de una casa cujo estado constitua iminente perigo. $\mathbf{E}$ pode ainda o fato encerrar uma declaração de vontade, confundindo-se então com $o$ ato jurídico. ${ }^{51}$

Dessas referências se pode ver quo não há uniformidade de pontos de vista na conceituação dos fatos administrativos, aos quais numerosos autores não fazem sequer alusão, limitando-se a examinar a teoria dos fatos jurídicos em geral.

De resto, parece que na esfera do direito administrativo não se faz necessária a elaboração de uma teoria especial sôbre o fato jurídico que, a rigor, no sentido estrito, compreende apenas o fato natural, involuntário, e assim regulado apenas em seus efeitos.

Como quer que seja, as operações materiais da atividade administrativa, tôdas elas decorrentes da ação humana, não são necessèriamente precedidas de um ato; pode-se dizer mesmo que não pressupõem a existência do ato, como no caso de obra, medida ou diligência não autorizadas.

48 Principios de Der. Adm., Buenos Aires, 1942, p. 56.

49 Op. cit., p. 96.

50 Op. cit., p. 44.

51 Op. cit., p. 43. 


\section{CONCLUSÃo}

23. Em face das considerações expendidas sôbre a matéria, tendentes apenas a fixar o conceito do ato administrativo, sım entrar no exame de sua formação, de seus elerrentos, classificação, e efeitos, o que suscitaria novas e numerosas teses - cumpre-nos enunciar resumidamente as conclusões assentadas sôbre os pontos versados, nos aspectos de maior relêvo.

Uma primeira proposição ficou esboçada quanto aos sistemas de discrime das funções do Estado: a de que essas funçóes devem ser consideradas e determinadas do ponto de vista objet vo ou material, levando em conta apenas o conteúdo da atividade desenvolvida, por seus característicos essenciais e invariáveis.

Despreza-se, conseqüentemente, para o efeito de caracterizar a função, a qualidade do órgão ou agente do poder público çue a exerça, visto que a separação das funções não coincide com a dos órgãos pelos quais se distribui a ação de govêrno, considerada do amplo sentido.

Também se exclui o critério, mais generalizado na doutrina, que toma como índice aferidor da natureza ou da peculiaridade de cada funçäo os fins do Estado, sejam os fins ideais ou abstratos, segundo a concepção de JELlinek. sejam os fins práticos ou o objeto sôbre que recai a ação do poder público. Na ampla, variada e inconstante finalidade do Estado não se encontram elementos ou característicos que ofereçam base segura e definitiva para um sistema de discriminação das funções. Aí se treta, antes, de atribuições que de funções do Estado.

O que há a considerar é a forma especinica daquela açăo; e essa forma aparece segundo as modiŕccações impostas à ordem jurídica, entendida não só no sentido do direito objetivo cono das situações subjetivas existentes num dado momento.

Os efeitos, enfim, que os atos do poder público determinam é que, em suma, oferecem o critério de diferenciação das funções; se não um critério rígido e perfeito, pelo menos fundamental.

Em razão dêsses efeitos, os atos, como vimos, se classificam em diversas categorias, segundo a doutrina de DuguiT e de JÈZE.

24. Aceita, em princípio, essa doutrina, que importa em aribuir caráter exclusivamente jurídico a tôdas as funções do Estado, deve-se considerar, particularmente quanto à administração, cue esta realiza freqüente e essencialmente operações ou ações nuateriais sem conteúdo ou efeito jurídico, as quais, por isso, hão de ser compreendidas no conceito da função administrativa. 
Esta função, notou BonNARD, se realiza por meio de atos de variada natureza: “os atos administrativos não são, com efeito, de um tipo único do ponto de vista material, como os atos legislativos." 62

Uma segunda conclusāo surge, portanto: a de que a função administrativa, compreendendo tanto os atos jurídicos como os materiais, inclusive os que constituem simples preparação ou meio para a realização dos primeiros, pode ser definida, segundo a fórmula concisa de SEABra FAGUndes, "como aquela pela qual - Estado determina situações jurídicas individuais, concorre para a sua formação e pratica atos materiais".

25. A terceira proposição, já agora relativa ao ato administrativo, é a de que êste só se refere à atividade jurídica da administração, sendo, em síntese, o ato que determina situações jurídicas para casos individuais, compreendendo tanto os atos subjetivos como os atos-condição, mas excluindo os atos materiais.

Porque um ato material, como pondera JÈzE, não é mais, do ponto de vista da técnica jurídica, do que "a condição de aplicabilidade a um indivíduo de um status legal ou a condição para o exercício de um poder legal. Nunca, porém, um ato material cria uma situação jurídica qualquer". .s

Não se enquadra, portanto, a espécie na conceituação do ato administrativo como ato jurídico.

Procedendo a aprofundada análise do tema, Sílvio Trentro conclui por afirmar que a noção do ato administrativo deve corresponder ao conceito geral do ato jurídico, aí encontrando seus elementos fundamentais. Doutra maneira se produziria uma confusão terminológica de tôda inconveniência, dando lugar a tôda sorte de classificações. Cita, a êste propósito, a definição que condensa no ato administrativo tôda a atividade da administração, nela entrando mesmo os atos privados, os consistentes em simples

52 Op. cit., p. 43.

E esclarece:

"II intervient d'abord des actee juridiques à portée individuelle, c'est-à-dire des actes mubjectifs et des actes-condition, et cela, wou toutes leurs formes quant au mode de manifeatation de la volonté".

La fonction sdministrative g'exerce aussi au moyen d'actes matériels. Ces actes constituent une part très importante de l'activité administrative. Ainsi la fonction administrative n'est plus, comme la fonction législative, de nature exclusivemente juridique, puisque, par les actes matériel,, elle produit autre chose que des effets de droit".

53 Op. cit., p. 74. 
aç̃es materiais e os negócios juridicos administrativos, o que levou KoRMarrn a admitir quatro significaçōes diversas da expressão. ${ }^{5 /}$

A observação é de evidente interêsse e relevância porque a: definições devem fundar-se em terminologia precisa, encerrando uma sintese exata do objeto definido.

Iis porque, com irrecusável fundamente, o erudito autor italiano concluiu que "se devem a priori excluir da noção de ato administrativo tôảs as várias formas de atividade administrativa que não possam considerar-se como manifestações de vontade em facı cas quais a ordem jurídica reconheça a passibilidade de produzir determinados efeitos", concluindo: "l'atto per consegisenza dovrà ritenersi una specie della categoria generale rappresentata dall'at. tività amministrativa".

$E$ fundamental, portanto, no conceito de ato administrativa, uma declaração de vontade produzindo um efeito de direito.

54. L'Aito Amministrativo, 1915, p. 124:

"A-... te'i Eznlicitamente riconosce che del concetto si possano avere quattro signif:cazioni C.Ciesnf: $1^{\circ} 1^{\prime}$ atto emministrativo in senso latissimo a cui corrisponderebbe la definizic-o precedenternente riportata; $20^{\circ}$ l'atto amministrativo ir senso lato, dal quaje dovrebjo.o esciujersi gli atti puramente privati e le azioni puramente materiali; $3 .^{\circ} 1^{\prime}$ atto gauministritivo ia senso stietto, il quale resulterebbe dalla eliminazione dal concetto preotdente dellis azioni giundiche, intese queste nel senso che più avanti vedremo; $4 .^{\circ}$ 1'atlo amministritivo in senso strettissimo, nella cui nozione non dovrehbero comprendersi quai negcri giulidice che non provengono da vere autorità amministrative ma da organi giurisdizionel:".

55 Op. cit., p. 124. 